\title{
Forage Establishment: Weather Effects on Stubble vs. Fal- low and Fall vs. Spring Seeding
}

\author{
RICHARD H. HART AND JOHN G. DEAN
}

\section{Abstract}

Improved pastures are a valuable forage resource in the Central Great Plains, but ranchers need to know which seeding techniques provide the best chance of successful establishment of such pastures. We compared late fall vs. spring seedings of 5 grasses and 2 legumes in barley stubble or fallow. Four directions of stubble rows were compared for snow catchment and effect on forage establishment. Stubble rows in any direction had little effect on snow catch or establishment, and there was little difference between stubble and fallow. Spring seeding gave better stands than fall seeding in the kind of weather most often encountered in the Central Great Plains. Days from seeding to emergence were controlled by soil temperature and timing and amount of precipitation. Stands were negatively correlated with the time required for emergence.

Seeded stands of introduced or improved grasses and legumes are valuable for pasture and hay in the Central Great Plains, but lack of precipitation and low spring and fall temperatures often prevent establishment of satisfactory stands. Fall seedings into dry soil have been recommended (Gomm 1974, Lang et al. 1975, Seamands 1976, USDA-SCS 1968); seed is then in place to take advantage of the first favorable germinating conditions in the spring. Warm-season grasses usually establish better when seeded in spring (Lang et al. 1975). Mulches and standing stubble, which catch snow for additional soil water and reduce variations in soil temperatures (Greb 1980, Aase and Siddoway 1980, Schuman et al. 1980), have been used in attempts to improve establishment. Stubble persists longer and is cheaper than straw mulch, and retains slightly more snow (Schuman et al. 1980).

In this study we compared the effects of stubble vs. fallow and late fall vs. spring seedings on the establishment of 5 grasses and 2 legumes. Barley rows were planted in 4 directions to evaluate the consequences of orientation of stubble on the effectiveness of stubble mulch.

\section{Materials and Methods}

The study was done on Wheatridge loam, a fine-loamy mixed mesic Aridic Argiustoll. Barley (Hordeum vulgare L.) was drilled in rows $20 \mathrm{~cm}$ apart at $22 \mathrm{~kg}$ seed/ ha on 13 June 1977, 29 May 1978, and 22 May 1979, in plots $12 \times 15 \mathrm{~m}$. Each of 4 replications included 4 plots of barley, with rows oriented north to south (N-S), northeast to southwest (NE-SW), east to west (E-W), or southeast to northwest (SE-NW), and 1 fallow plot. At the milk to soft dough stage, the barley was cut to a $15-\mathrm{cm}$ stubble and the cut material removed. The amount of stubble remaining was not measured, but barley stands were excellent every year.

In early winter of each year that barley was seeded, and in the following spring (see Table 1 for planting dates), desert wheatgrass (Agropyron desertorum [Fisch.] Schult. cv. 'Nordan'), western wheatgrass (A. smithii Rydb. cv. 'Rosana'), Russian wildrye (Psathyrostachys juncea [Fisch] Nevski cv. 'Vinall'), blue grama (Bouteloua gracilis [H.B.K.] Lag. ex Griffiths cv. 'KS 1483'), sand dropseed (Sporobolus cryptandrus [Torr.] Gray), cicer milkvetch (Astragalus cicer L. cv. 'Monarch'), and alfalfa (Medicago sativa $\mathrm{L}$. cv. 'Baker') each were drilled in a single row perpendicular to the stubble rows in each stubble plot and east to west in each fallow plot. Rows were $7 \mathrm{~m}$ long and $0.5 \mathrm{~m}$ apart, in the center of the barley or fallow plot. Seeding rate was 37 pure live seeds, as

Authors are agronomist and former agronomist (deceased), USDA, Agricultural Research Service, High Plains Grasslands Research Station, 8408 Hildreth Road, Cheyenne, Wyo. 82009 .

Manuscript accepted 8 August 1985 determined in greenhouse emergence test, per meter of row. Planting depths were $2 \mathrm{~cm}$ for blue grama, $4 \mathrm{~cm}$ for cicer milkvetch, and $3 \mathrm{~cm}$ for the other 5 species.

Table 1. Stands of forages (mean of seven species) seeded at High Plains Grasslands Research Station, Cheyenne, Wyoming, in fallow or barely stubble with four row orientations.

\begin{tabular}{|c|c|c|c|c|c|c|}
\hline \multirow[b]{2}{*}{ Seedbed treatment } & \multicolumn{6}{|c|}{ Seeding dates } \\
\hline & $\begin{array}{l}13-19 \\
\operatorname{Dec} 77\end{array}$ & $\begin{array}{c}27-28 \\
\text { Mar } 78\end{array}$ & $\begin{array}{c}16-22 \\
\text { Nov } 78\end{array}$ & $\begin{array}{c}6-7 \\
\operatorname{Mar} 79\end{array}$ & $\begin{array}{c}20-21 \\
\operatorname{Dec} 79\end{array}$ & $\begin{array}{c}25 \\
\text { Mar } 80\end{array}$ \\
\hline & & -Pla & $\mathrm{nts} / \mathrm{m}$ & w, c & & 1080 \\
\hline & & 1780 & & & & \\
\hline \multirow[t]{2}{*}{$\begin{array}{l}\text { Fallow } \\
\text { Stubble, row N-S } \\
\text { NE-SW } \\
\text { E-W } \\
\text { SE-NW }\end{array}$} & $\begin{array}{l}11 b^{1} \\
8 c \\
9 b c \\
10 b c \\
15 b\end{array}$ & $\begin{array}{l}21 \mathrm{a} \\
27 \mathrm{a} \\
22 \mathrm{a} \\
21 \mathrm{a} \\
26 \mathrm{a}\end{array}$ & $\begin{array}{l}9 \mathrm{a} \\
7 \mathrm{ab} \\
6 \mathrm{bc} \\
7 \mathrm{ab} \\
8 \mathrm{ab}\end{array}$ & $\begin{array}{l}7 \mathrm{ab} \\
4 \mathrm{c} \\
3 \mathrm{c} \\
4 \mathrm{c} \\
4 \mathrm{c}\end{array}$ & $\begin{array}{l}9 \mathrm{c} \\
5 \mathrm{~d} \\
6 \mathrm{~cd} \\
6 \mathrm{~cd} \\
5 \mathrm{~d}\end{array}$ & $\begin{array}{l}13 \mathrm{~b} \\
17 \mathrm{a} \\
12 \mathrm{~b} \\
14 \mathrm{ab} \\
15 \mathrm{ab}\end{array}$ \\
\hline & \multicolumn{2}{|c|}{ Fall 1978} & $\mathbf{F}$ & 979 & \multicolumn{2}{|c|}{ Fall 1980} \\
\hline $\begin{array}{l}\text { Fallow } \\
\text { Stubble, rows N-S } \\
\text { NE-SW } \\
\text { E-W } \\
\text { SE-NW }\end{array}$ & $\begin{array}{l}42 \mathrm{~d} \\
41 \mathrm{~d} \\
43 \mathrm{~d} \\
45 \mathrm{~cd} \\
54 \mathrm{bc}\end{array}$ & $\begin{array}{l}61 \mathrm{ab} \\
64 \mathrm{ab} \\
59 \mathrm{ab} \\
59 \mathrm{ab} \\
69 \mathrm{a}\end{array}$ & $\begin{array}{l}41 \mathrm{bc} \\
49 \mathrm{ab} \\
48 \mathrm{ab} \\
49 \mathrm{ab} \\
53 \mathrm{a}\end{array}$ & $\begin{array}{l}39 \mathrm{bc} \\
32 \mathrm{c} \\
31 \mathrm{c} \\
39 \mathrm{c} \\
35 \mathrm{c}\end{array}$ & $\begin{array}{l}39 \mathrm{~b} \\
36 \mathrm{~b} \\
34 \mathrm{~b} \\
35 \mathrm{~b} \\
36 \mathrm{~b}\end{array}$ & $\begin{array}{l}52 \mathrm{a} \\
56 \mathrm{a} \\
51 \mathrm{a} \\
56 \mathrm{a} \\
57 \mathrm{a}\end{array}$ \\
\hline
\end{tabular}

IWithin each time in which plants were counted or stand was estimated, figures followed by the same lower-case letter are not significantly different $(P<0.05)$.

Emergence dates of the first seedlings in each row were recorded. Plants were counted in three $1-\mathrm{m}$ segments of each row when it appeared that no more plants would emerge. In September of the year of emergence and in May of the following year, stands were estimated. We placed a frame of 5 adjacent $10-\mathrm{cm}$ squares over each row at 2 randomly chosen locations and estimated the percent of the row in each square that was covered by plant crowns.

Precipitation was measured in a shielded rain gauge at Station headquarters, about $700 \mathrm{~m}$ from the plots. A thermograph at the same location recorded soil temperatures $38 \mathrm{~mm}$ below the soil surface. Soil degree-days were calculated as the cumulative sum of the mean of daily high and low temperatures, minus $5^{\circ} \mathrm{C}$, omitting days with a mean temperature below $5^{\circ} \mathrm{C}$. The base temperature of $5^{\circ} \mathrm{C}$ was selected as a compromise between 0 and $10^{\circ} \mathrm{C}$, which might have been more realistic bases for cool- and warm-season species, respectively.

During the winter of 1977-78, snow depth was measured after each snow at 24 predetermined locations in each plot of 1 replication. From 15 March to 7 June 1978, thermocouples were placed 25 $\mathrm{mm}$ below the soil surface at 3 locations in each plot of 1 replication, and soil temperatures were read at 1 pm every 2 or 3 days.

Date of emergence, plant count, and stand data were analyzed by analysis of variance. Differences in emergence date between fall and spring seeding within a species were separated by the T-test. Differences between species or seed bed treatments by seeding dates were separated by Duncan's multiple range test. Probability level was set at 0.05 . 
Table 2. Dates of emergence of seven forage species seeded fall or spring (means of fallow and barley stubble) at Cheyenne, Wyoming.

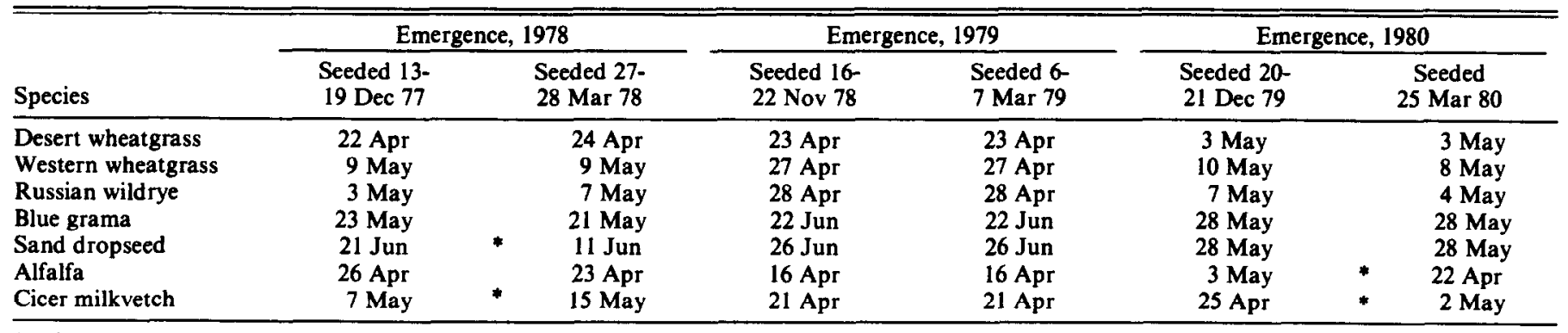

*Indicates emergence dates from fall and spring seedings were significantly different $(P>0.05)$.

\section{Results and Discussion}

\section{Stubble vs. Fallow and Stubble Row Orientation}

Seedbed treatment had no effect on date of emergence and effect on stand was minimal (Table 1 ); there were no seedbed $X$ species interactions. In 1979, when emergence of all species was poor under all treatments, spring plant count following spring seeding was higher from fallow than from any stubble treatment. Some other small and inconsistent differences in spring plant count were noted, but nearly all had disappeared when stand was estimated in the fall.

Winds at Cheyenne from November through April are predominantly from the west or northwest (U.S. Dept. of Commerce 1968). North-south or NE-SW stubble rows would be expected to catch more snow and produce better stands than other orientations, but this was not observed. Stubble caught snow, but retained it for only a few days until the wind changed and blew it away. The storm of 9 November 1977 was typical. Immediately after the storm, which was accompanied by a north-northwest wind, mean snow depths in N-S, NE-SW, E-W, and SE-NW stubble were 10, 15, 17, and 14 $\mathrm{cm}$ respectively, while only a trace remained on fallow. Two days later, a west wind removed nearly all the snow from the $E-W$ rows and left a mosaic of bare ground and patches of snow of varying depths on the other orientations. Because of the quick removal of snow, and the fact that most winter snow in southeast Wyoming sublimes rather than melts, it is unlikely that winter snow adds much to soil water. Aase and Siddoway (1980) noted that in one storm in northeastern Montana, a $19-\mathrm{cm}$ stubble retained $4 \mathrm{~cm}$ of water equivalent in snow, vs. $3 \mathrm{~cm}$ on bare ground. However, they did not report how much of this moisture entered the soil. Greb (1980) reported $2.5 \mathrm{~cm}$ more water stored under wheat stubble than under bare ground at the end of the winter near Akron, Colorado. This additional water was distributed through the profile; very little was in the top few centimeters where it was available to germinating seeds and emerging seedlings.

Stubble effects on soil temperature also were small. From 15 March to 7 June 1978 , mean soil temperatures $25 \mathrm{~mm}$ deep, measured at $1 \mathrm{pm}$, averaged $1.4^{\circ} \mathrm{C}$ lower under stubble than under fallow. There were no differences among stubble orientations and no date $X$ treatment interactions. Aase and Siddoway (1980) reported that, with no snow cover, soil temperatures $5 \mathrm{~cm}$ below bare ground and $19-\mathrm{cm}$ stubble decreased 0.77 and 0.64 degrees, respectively, for each degree decrease in air temperature $155 \mathrm{~cm}$ above the ground. Thus temperatures under stubble and bare ground were similar at high air temperatures during the day, but it was warmer under stubble when the air was colder.

\section{Fall vs. Spring Seeding: Date of Emergence}

Seeding date had little effect on emergence date (Table 2). The only consistent difference noted was that cicer milkvetch emerged about a week earlier from fall than from spring seeding in 1978 and 1980; cicer emerged on the same date from both seedings in 1979.

Date of emergence was controlled by complex interactions of soil temperature and precipitation. More soil degree-days above $5^{\circ}$ $C$ accumulated before emergence of cool-season grasses and legumes from spring seeding in 1978 than in 1979 or 1980 (Table 3)
Table 3. Cummulative soil degree-days $\left(38 \mathrm{~mm}\right.$ deep, base $\left.5^{\circ} \mathrm{C}\right)$ at Cheyenne, Wyoming until emergence of spring-seeded cool-season grasses and legumes.

\begin{tabular}{lccc}
\hline \hline Grass & 1978 & 1979 & 1980 \\
\hline & & Soil degree-days- & \\
\cline { 2 - 4 } Desert wheatgrass & 139 & 102 & 115 \\
Western wheatgrass & 196 & 126 & 153 \\
Russian wildrye & 194 & 134 & 122 \\
Alfalfa & 132 & 52 & 52 \\
Cicer milkvetch & 241 & 88 & 109 \\
\hline
\end{tabular}

because of limited precipitation in the month after seeding (Fig. 1). In 1979 and 1980, major precipitation events occurred 12 and 3

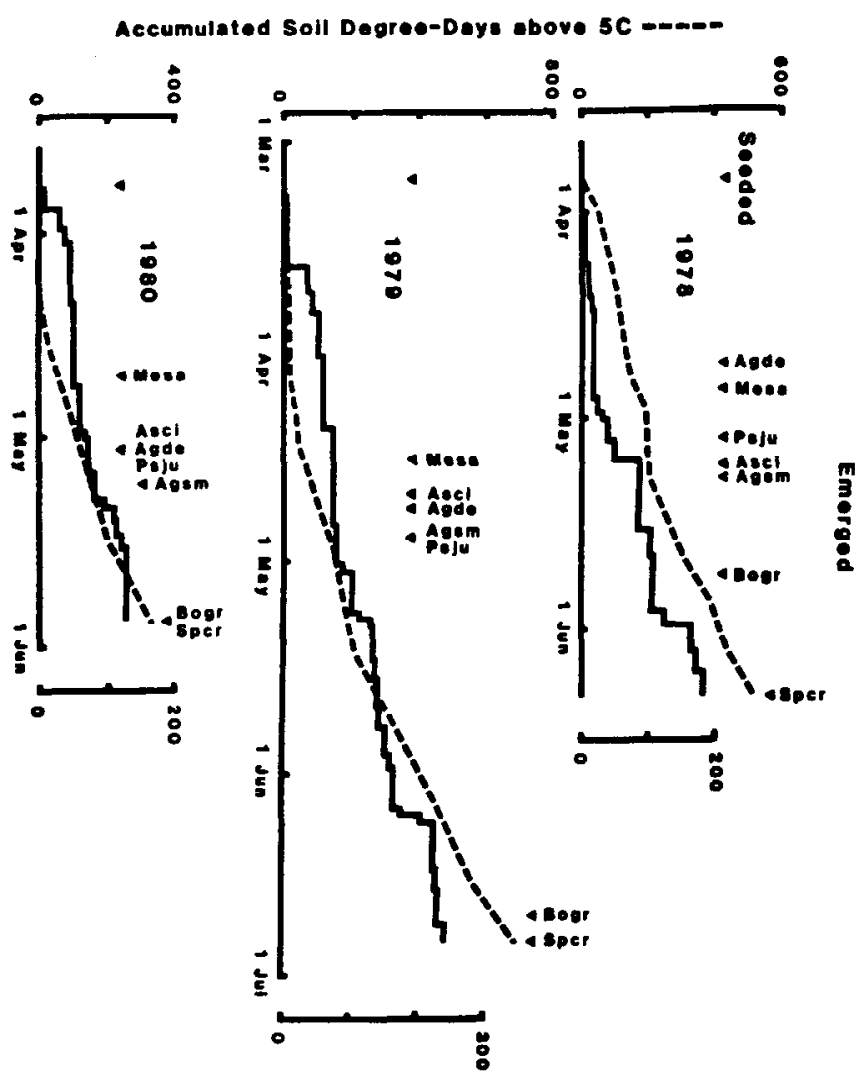

Accumulated Precipltation, $\mathrm{mm}$

Fig. 1. Cumulative soil degree-days and precipitation, and dates of seeding and emergence of 7 forage species spring-seeded into barley stubble or fallow at Cheyenne Wyoming. (Agde = desert wheatgrass, Agsm $=$ western wheatgrass, Asci = cicer milkvetch, Bogr = blue grama, Mesa $=$ alfalfa, Psju = Russian wildrye, and Spcr = sand dropseed). 
days, respectively, after seeding. Emergence of cool-season grasses and legumes occurred more days after planting in 1979 than in 1980, because soil temperatures were lower in 1979 (Fig. 1), but accumulated soil degree-days were nearly the same in both years (Table 3).

The relative number of soil degree-days required for emergence of the different species in the field parallels the temperature requirements for germination found under controlled conditions. Desert wheatgrass germinates better at low temperatures than does Russian wildrye (McGinnies 1960) and emerges after fewer degreedays. Western wheatgrass has a higher temperature requirement than Russian wildrye (Sabo et al. 1979). Townsend and McGinnies (1972) found cicer milkvetch germinates more slowly than alfalfa at low temperatures, and we noted it requires more soil degree-days.

Emergence of warm-season grasses was much delayed in 1979, when median daily soil temperatures were not consistently above $10^{\circ} \mathrm{C}$ until mid-May; soil temperatures favorable for germination of blue grama and sand dropseed (Sabo et al. 1979) were not reached until then. But late May and early June of 1979 were dry; the first major precipitation event $(60 \mathrm{~mm})$ in this period occurred 6-8 June (Fig. 1). Blue grama and sand dropseed emerged 16 and 20 days ( 175 and 225 soil degree-days), respectively, thereafter. In 1978 , and 1980 , median daily soil temperatures exceeded $10^{\circ} \mathrm{C}$ by early May and mid-April, respectively. In $197838 \mathrm{~mm}$ of rain fell on 6 May; blue grama and sand dropseed emerged 15 and 36 days (97 and 298 soil degree-days) later. Blue grama may have initiated germination earlier, during a 12-day period beginning 19 April when median soil temperature was above $10^{\circ} \mathrm{C}$. Sabe et al. (1979) indicated that blue grama germinates at lower temperatures than does sand dropseed. Blue grama emerged 33 days or 183 soil degree-days after 19 April. In 1980, 9 mm of rain fell on 23 April; soil temperatures were favorable and both blue grama and sand dropseed emerged 35 days and 271 degree-days later.

Thus the response of emergence to temperature is modified by timing and amount of precipitation and the time when a threshold temperature for germination is reached.

\section{Fall vs. Spring Seeding: Stand}

Spring seeding produced more plants of all cool-season grasses and legumes than did fall seeding in 1977-78 and 1979-80 (Table

Table 4. Stands of seven forage species seeded in fall vs. spring (mean of fallow and barley stubble) at Cheyenne, Wyoming.

\begin{tabular}{|c|c|c|c|c|c|c|}
\hline \multirow[b]{2}{*}{ Seedbed treatment } & \multicolumn{6}{|c|}{ Seeding dates } \\
\hline & $\begin{array}{c}13-19 \\
\text { Dec } 77\end{array}$ & $\begin{array}{c}27-28 \\
\text { Mar } 78\end{array}$ & $\begin{array}{c}16-22 \\
\text { Nov } 78\end{array}$ & $\begin{array}{c}6-7 \\
\operatorname{Mar} 79\end{array}$ & $\begin{array}{l}20-21 \\
\text { Dec } 79\end{array}$ & $\begin{array}{c}25 \\
\operatorname{Mar} 80\end{array}$ \\
\hline \multirow{9}{*}{$\begin{array}{l}\text { Crested wheatgrass } \\
\text { Western wheatgrass } \\
\text { Russian wildrye } \\
\text { Blue grama } \\
\text { Sand dropseed } \\
\text { Alfalfa } \\
\text { Cicer milkvetch }\end{array}$} & \multicolumn{6}{|c|}{ Plants/m of row, counted;- } \\
\hline & \multicolumn{2}{|c|}{ Spring 1978} & \multicolumn{2}{|c|}{ Spring 1979} & \multicolumn{2}{|c|}{ Spring 1980} \\
\hline & \multirow{7}{*}{$\begin{array}{l}21 \mathrm{~b}^{1} \\
10 \mathrm{~cd} \\
20 \mathrm{~b} \\
5 \mathrm{def} \\
<1 \mathrm{e} \\
8 \mathrm{cde} \\
12 \mathrm{c}\end{array}$} & \multirow{7}{*}{$\begin{array}{l}34 \mathrm{a} \\
24 \mathrm{~b} \\
32 \mathrm{a} \\
11 \mathrm{~cd} \\
1 \mathrm{e} \\
25 \mathrm{~b} \\
35 \mathrm{a}\end{array}$} & \multirow{7}{*}{$\begin{array}{l}13 \mathrm{a} \\
11 \mathrm{ab} \\
11 \mathrm{ab} \\
<1 \mathrm{e} \\
1 \mathrm{e} \\
9 \mathrm{bc} \\
7 \mathrm{~cd}\end{array}$} & \multirow{7}{*}{$\begin{array}{l}7 \mathrm{~cd} \\
6 \mathrm{~cd} \\
7 \mathrm{~cd} \\
<1 \mathrm{e} \\
<1 \mathrm{e} \\
7 \mathrm{~cd} \\
4 \mathrm{~d}\end{array}$} & \multirow{7}{*}{$\begin{array}{c}9 \mathrm{~d} \\
8 \mathrm{de} \\
11 \mathrm{~cd} \\
3 \mathrm{~g} \\
4 \mathrm{efg} \\
<1 \mathrm{~g} \\
7 \mathrm{def}\end{array}$} & \multirow{7}{*}{$\begin{array}{l}26 \mathrm{a} \\
14 \mathrm{c} \\
22 \mathrm{~b} \\
4 \mathrm{fg} \\
2 \mathrm{~g} \\
13 \mathrm{c} \\
20 \mathrm{~b}\end{array}$} \\
\hline & & & & & & \\
\hline & & & & & & \\
\hline & & & & & & \\
\hline & & & & & & \\
\hline & & & & & & \\
\hline & & & & & & \\
\hline & \multicolumn{2}{|c|}{ Fall 1978} & \multicolumn{2}{|c|}{ Fall 1979} & \multicolumn{2}{|c|}{ Fall 1980} \\
\hline & 63 & 80 & 63 & 50 & e & 81 \\
\hline eatgrass & $51 \mathrm{ef}$ & $65 \mathrm{~cd}$ & 84 & 56 & & \\
\hline & & & & & & \\
\hline Blue & $31 \mathrm{~g}$ & $49 \mathrm{e}$ & $4 \mathrm{e}$ & 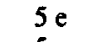 & & 19 \\
\hline dro & $1 \mathrm{~h}$ & $12 \mathrm{~h}$ & 0 & 5 & & \\
\hline & & & & 41 & 3 & \\
\hline & & & & $42 d$ & & $74 \mathrm{ab}$ \\
\hline
\end{tabular}

'Within each time in which plants were counted or stand was estimated, figures followed by the same lower-case letter are not significantly different $(P<0.05)$.
4). All fall 1979 seedings were damaged by large cracks which developed in the soil during the winter of 1979-80, in many cases in the seeded rows. These cracks allowed the soil to dry, and seeds and seedlings may have fallen into the cracks to depths too great for emergence.

Fall seeding in 1978 produced better stands of cool-season grasses than spring seeding in 1979; this may seem paradoxical because the winter of 1978-79 was very cold. December and January mean temperatures were -7.4 and $-9.6^{\circ} \mathrm{C}$ respectively, vs. -1.7 and -5.7 in $1977-78$ and -1.2 and -6.6 in 1979-80. However, the difference was not caused by high plant counts from fall seeding; they were about the same as counts from fall 1979 seeding, and except for western wheatgrass, lower than counts from fall 1977 seeding. The difference came from the very low counts from seeding in the cold, dry spring of 1979 (Table 4).

Legume plant counts from spring and fall seedings were not significantly different in 1978-79, again because spring-seeded stands were much poorer than in other years while fall-seeded stands were about the same in all years (Table 4). Alfalfa seeded in fall 1979 produced very few plants because of heavy rabbit damage at emergence.

Counts of warm-season grasses did not differ between seeding dates in any year. Blue grama produced a fairly good stand when seeded in spring 1978, when the earliest date of warm soil temperatures coincided with the first heavy spring rain. Otherwise stands of warm-season grasses were disappointing.

Fall stands of all species except western wheatgrass were closely correlated with preceding spring plant counts $\left(r^{2}=0.89^{* *}\right)$. Western wheatgrass is strongly rhizomatous and a few plants can spread into a good stand (Table 4). Stands of all species in the spring one year after emergence were so closely correlated with stands in the preceding fall $\left(r^{2}=0.92^{* *}\right)$ that they are not reported.

Fall seeding produced better stands than spring seedings only in the year when spring weather was most unfavorable for establishment. Otherwise spring seeding was superior. Inspection of past weather records at Cheyenne indicate spring seeding will produce better stands than fall seeding in most years. Plant counts from spring seedings of all species except cicer milkvetch were negatively correlated with days from seeding to emergence $\left(r^{2}=.71\right.$ to .89$)$. Better stands should be produced by seeding in April, when soils are warmer, probability of precipitation is greater, and emergence is more rapid, rather than in March.

\section{Literature Cited}

Anse, J.K., and F.H. Siddoway. 1980. Microclimate of winter wheat grown in standing stubble of three heights. Proc. Tillage Symp., 9-11 Sep. 1980. Bismarck, N.Dak. p. 102-118.

Gomm, F.B. 1974. Forage species for the Northern Intermountain Region. A summary of seeding trials. USDA Tech. Bull. 1479.

Greb, B.W. 1980. Snowfall and its potential management in the semiarid Central Great Plains. USDA-SEA Agr. Rev. Man. ARM-W-18.

Lang, R., F. Rauzi, W. Seamands, and G. Howard. 1975. Guidelines for seeding dryland range, pasture, and disturbed lands. Wyoming Agr. Exp. Sta. Bull. 621.

MeGinnies, W.J. 1960. Effects of moisture stress and temperature on germination of six range grasses. Agron. J. 52:159-162.

Sabo, D.G., G.V.Johnson, W.C. Martin, and E.F. Aldon. 1979. Germination requirements of 19 species of arid land plants. USDA Forest Serv. Res. Paper RM-210.

Schuman, G.E., E.M. Taylor, F. Rauzi, and G.S. Howard. 1980. Standing stubble versus crimped straw mulch for establishing grass on mined lands. J. Soil Water Conserv. 35:25-27.

Seamands, W.J. 1976. 1976-78 Wyoming crop recommendations. Univ. Wyoming Agr. Ext. Serv. Pub. 3-76-5M-15.

Townsend, C.E., and W.J. MeGinnies. 1972. Temperature requirements for seed germination of several forage legumes. Agron. J. 64:809-812.

U.S. Dep. of Agriculture, Soil Conservation Service. 1976. Pasture and hayland planting. SCS Wyoming Tech. Guide 512.

U.S. Dep. of Commerce. 1968. Climatic atlas of the United States. Environmental Sciences Service Admin., Environmental Data Service, Washington, DC. 